\title{
Studies on Variability, Heritability and Genetic Advance in Okra [Abelmoschus esculentus (L.) Moench.]
}

\author{
Ullangula Sravanthi* \\ Department of Horticulture, Dr. PDKV, Akola, Maharashtra, India \\ *Corresponding author
}

A B S T R A C T

\begin{abstract}
Keywords
Okra, Variability,

Heritability,

Genetic advance.

Article Info

Accepted:

17 September 2017

Available Online:

10 October 2017

Twenty one accessions of okra were assessed for variability for 12 characters. Highly significant differences were observed among the accessions. High phenotypic and genotypic coefficient of variation was observed for per cent incidence of YVMV, yield per plant, fruit weight, and number of fruits per plant indicating the existence of wider genetic variability for these traits in the germplasm. High heritability accompanied with high genetic advance was noticed for yield per plant, fruit weight and number of fruits per plant suggesting that they can be improved through direct selection due to predominant additive variation.
\end{abstract}

\section{Introduction}

Okra [Abelmoschus esculentus (L.) Moench.] is a member of the family Malvaceae and an important vegetable crop grown in tropical and subtropical regions of the world. The green tender fruits of okra are good source of carbohydrate, protein, vitamins (A, B and C) and rich in calcium, potassium and other mineral matters. It contains $1.9 \mathrm{~g}$ protein, 1.2 $\mathrm{g}$ fiber, $1.5 \mathrm{mg}$ Fe and $88 \mathrm{IU}$ Vit-A per $100 \mathrm{~g}$ of edible portion. India is a major okra producing country in the world comprising of 72 per cent of total area under okra. The area under okra cultivation in India is 0.507 M.ha with production of $5.853 \mathrm{MT}$ and productivity of $11.50 \mathrm{MT} / \mathrm{ha}$, containing 5.8 per cent of the total area under vegetable crops and 3.9 per cent of total vegetable production (NHB database, 2014-15). Genetic improvement of any crop mainly depends on the amount of genetic variability present in the population and the germplasm serves as a valuable source of base population and provide scope for wide variability (Gavade and Ghadage, 2015). Further, the crop exhibits rich genetic diversity and scope for improvement for various horticultural traits. Heritability is the heritable portion of phenotypic variance. The estimates of heritability help the plant breeder in selection of elite genotypes from diverse genetic populations. Heritability indicates only the effectiveness with which selection of a genotype can be based on phenotypic performance but it fails to indicate the expected genetic progress in one cycle of selection. Heritable variation can be effectively used with greater degree of 
accuracy when heritability is studied in conjunction with genetic advance (Johnson et al., 1955). Genetic advance denotes the improvement in the mean genotypic values of selected families over base population and thus helps the breeder to select the progenies in the earlier generation itself. An improvement in yield and quality of okra is normally achieved by selecting the genotypes with desirable character combination existing in nature or by hybridization. With this objective, the present investigation was carried out with okra germplasm.

\section{Materials and Methods}

The present study was carried out at the Main Garden Department of of Horticulture, Dr. Panjabrao Deshmukh Krishi Vidyapeeth of Akola during spring summer season 2014, Maharashtra. The genotypes tested were consisted of the lines collected from different localities. The list of the evaluated genotypes along with their sources was illustrated in Table 1. Each entry was sown at $60 \times 30 \mathrm{~cm}$ spacing, accommodating 20 plants in each plot. The observations were recorded from five competitive plants from each replication on fifteen parameters viz., plant height, days to initiation of flowering, days to $50 \%$ flowering, internodal length $(\mathrm{cm})$, number of branches per plant, fruit length $(\mathrm{cm})$, diameter of fruit $(\mathrm{cm})$, fruit weight $(\mathrm{g})$, number of ridges on fruit, number of fruits per plant, yield per plant $(\mathrm{g})$, yield per plot $(\mathrm{kg})$, yield per hectare(q), percent fiber content, percent incidence of Y.V.M.V.

Observations were recorded from five randomly selected plants of each genotype in each replication. The data were analyzed by the methods of Cochran and Cox (1957) using mean values of random plants in each replication from all genotypes to determine significance of genotypic effects. Genotypic and phenotypic coefficients of variation were calculated using the formulae of Burton (1952). Broad sense heritability was calculated as per Lush (1940) and genetic advance estimated by the method of Johnson et al., (1955a). Categorization of genotypic coefficient of variation (GCV), phenotypic coefficient of variation (PCV) and genetic advance (GA) were done as per Sivasubramanian and Menon (1973) and heritability categorized as by Johnson et al., (1955).

\section{Results and Discussion}

The analysis of variance showed that the genotypes under study differed significantly among themselves for all the 12 characters (Table 2). The mean, range, genotypic (GCV) and phenotypic (PCV) coefficients of variation, heritability and genetic advance as per cent of mean for all the characters are presented in (Table 3). Wide range of variation could be recorded for per cent incidence of YVMV, yield per plant, fruit weight, number of fruits per plant. Sivasubramaniam and Madhava Menon (1973) suggested that the values greater than 20 per cent indicate the high phenotypic and genotypic coefficients of variation, the values ranged between 10 to 20 per cent indicate the moderate phenotypic and genotypic coefficients of variation, while the values less than 10 per cent indicate the low phenotypic and genotypic coefficients of variation.

Johnson et al., (1955a) reported that heritability along with genetic gain is more useful than the heritability alone, in predicting the resultant effect for selecting the best individuals. He categorized the heritability values, as the values greater than 60 per cent indicate the high heritability, the values ranged between 30 to 60 per cent indicate the moderate heritability, while the values less than 30 per cent indicate the low heritability. 
Table.1 List of 21 genotypes of okra under study

\begin{tabular}{|c|c|c|}
\hline Sr. No. & Name of the genotype & Source \\
\hline G-1 & GDO-4 & ARS,Sonapur \\
\hline G-2 & GDO-2 & ARS,Sonapur \\
\hline G-3 & GDO-3 & ARS,Sonapur \\
\hline G-4 & GDO-1 & ARS,Sonapur \\
\hline G-5 & GDO-6 & ARS,Sonapur \\
\hline G-6 & GDO-10 & ARS,Sonapur \\
\hline G-7 & GDO-15 & ARS,Sonapur \\
\hline G-8 & GDO-20 & ARS,Sonapur \\
\hline G-9 & Akola Bahar & Dr. P.D.K.V.,Akola \\
\hline G-10 & ArkaAnamika & IIHR,Banglore \\
\hline G-11 & AKO-106 & Dr. P.D.K.V.,Akola \\
\hline G-12 & AKO-114 & Dr. P.D.K.V.,Akola \\
\hline G-13 & AKO-118 & Dr. P.D.K.V.,Akola \\
\hline G-14 & Julie & Private Sector \\
\hline G-15 & Korchi & ARS,Sonapur \\
\hline G-16 & IC-90201 & NBPGR,New Delhi \\
\hline G-17 & IC-90221 & NBPGR,New Delhi \\
\hline G-18 & IC-90222 & NBPGR,New Delhi \\
\hline G-19 & IC-90253 & NBPGR,New Delhi \\
\hline G-20 & IC-90260 & NBPGR,New Delhi \\
\hline G-21 & IC-90267 & NBPGR,New Delhi \\
\hline
\end{tabular}

Table.2 Analysis of variance for fruit yield and its attributes in okra

\begin{tabular}{|c|c|c|c|c|}
\hline \multirow{2}{*}{$\begin{array}{c}\text { Sr. } \\
\text { No. }\end{array}$} & Characters & \multicolumn{3}{|c|}{ Mean sum of square } \\
\cline { 3 - 4 } & Replication & Genotypes & Error \\
\hline 1 & Plant height (cm) & 1.28 & 3459.97 & 119.64 \\
\hline 2 & $\begin{array}{c}\text { Days to initiation of first } \\
\text { flowering }\end{array}$ & 0.18 & 185.02 & 4.53 \\
\hline 3 & Internodal length (cm) & 0.00 & 25.95 & 1.87 \\
\hline 4 & $\begin{array}{c}\text { Number of Branches per } \\
\text { plant }\end{array}$ & 0.07 & 9.05 & 0.50 \\
\hline 5 & Fruit length (cm) & 0.52 & 116.75 & 6.63 \\
\hline 6 & Fruit diameter (cm) & 0.00 & 0.72 & 0.01 \\
\hline 7 & Fruit weight (g) & 0.01 & 257.78 & 2.72 \\
\hline 8 & Number of ridges on fruit & 0.24 & 38.74 & 2.91 \\
\hline 9 & Number of fruits per plant & 1.23 & 584.38 & 14.09 \\
\hline 10 & Yield per per plant & 115.96 & 95717.72 & 963.54 \\
\hline 11 & Per cent fiber content & 0.66 & 130.35 & 31.27 \\
\hline 12 & Per cent incidence of & 34.12 & 3122.22 & 215.87 \\
\hline
\end{tabular}


Table.3 Variability and genetic parameters for 12 characters in okra

\begin{tabular}{|c|c|c|c|c|c|c|c|c|}
\hline \multirow[t]{2}{*}{ S.No. } & \multirow[b]{2}{*}{ Characters } & \multirow[b]{2}{*}{ Mean } & \multicolumn{2}{|c|}{ Range } & \multirow[b]{2}{*}{$\begin{array}{c}\text { P.C.V. } \\
(\%)\end{array}$} & \multirow[b]{2}{*}{$\begin{array}{c}\text { G.C.V. } \\
(\%)\end{array}$} & \multirow{2}{*}{$\begin{array}{c}\text { Heritabi } \\
\text { lity } \\
(\%)\end{array}$} & \multirow{2}{*}{$\begin{array}{c}\text { Genetic } \\
\text { advance } \\
\text { (as a \% of } \\
\text { mean) }\end{array}$} \\
\hline & & & Lowest & Highest & & & & \\
\hline 1 & Plant height $(\mathrm{cm})$ & 56.45 & 45.66 & 71.33 & 13.68 & 13.33 & 94.99 & 26.77 \\
\hline 2 & $\begin{array}{l}\text { Days to initiation of first } \\
\text { flowering }\end{array}$ & 44.42 & 41.60 & 46.93 & 4.00 & 3.92 & 96.41 & 7.94 \\
\hline 3 & Internodal length $(\mathrm{cm})$ & 4.2 & 2.75 & 4.26 & 16.19 & 15.35 & 89.87 & 29.97 \\
\hline 4 & Number of Branches per plant & 3.26 & 2.59 & 4.26 & 12.24 & 11.74 & 92.01 & 23.20 \\
\hline 5 & Fruit length $(\mathrm{cm})$ & 9.92 & 6.56 & 12.83 & 14.45 & 13.85 & 91.94 & 27.37 \\
\hline 6 & Fruit diameter $(\mathrm{cm})$ & 1.45 & 1.30 & 1.64 & 7.63 & 7.54 & 97.64 & 15.36 \\
\hline 7 & Fruit weight $(\mathrm{g})$ & 8.56 & 5.06 & 12.35 & 24.07 & 23.88 & 98.43 & 48.81 \\
\hline 8 & Number of ridges on fruit & 5.49 & 5.0 & 7.26 & 15.16 & 14.34 & 89.50 & 27.95 \\
\hline 9 & Number of fruits per plant & 14.80 & 8.33 & 20.66 & 21.32 & 20.94 & 96.50 & 42.37 \\
\hline 10 & Yield per per plant & 127.71 & 69.2 & 221.13 & 31.43 & 31.19 & 98.51 & 63.77 \\
\hline 11 & Per cent fiber content & 11.76 & 9.67 & 14.37 & 13.94 & 11.75 & 70.97 & 20.39 \\
\hline 12 & Per cent incidence of YVMV & 13.88 & 5.0 & 26.66 & 53.70 & 51.03 & 90.30 & 99.89 \\
\hline
\end{tabular}

Similarly, the values greater than 20 per cent indicate high genetic advance, the values ranged between 10 to 20 per cent indicate moderate genetic advance, while the values less than 10 per cent indicate low genetic advance. The magnitude of PCV was higher than that of GCV for all the traits. The ratio of GCV and PCV indicate that some of characters were influenced by the environment. The GCV and PCV were high for per cent incidence of YVMV, yield per plant, fruit weight, number of fruits per plant; moderate for internodal length, number of ridges on fruit, fruit length, plant height, number of branches per plant, per cent fiber content; and low for days to initiation of first flowering, fruit diameter. Similar observations have been reported by Patil et al., (1996), Panda and Singh (1997), Dhankar and Dhankar (2002), and Mehta et al., (2006). The estimates of heritability in broad sense were high for all characters. In the present study high genetic advance was observed for all the characters except moderate for fruit diameter; less for days to initiation of first flowering.
Panse (1957) concluded that a character with high heritability in association with high genetic advance (in \% mean) is an indication of expression of additive gene action. Characters without such combination appear generally because of non-additive gene action (Liang and Walter, 1968). Therefore, it may be stated that among the characters under study, yield per plant, fruit weight, number of fruits per plant are likely to be operated by additive genes. Improvement in these characters would be effective by selection on the basis of phenotype. These results are in consonance with the earlier reports of Panda and Singh (1997), Dhankar and Dhankar (2002) and Mehta (2006).

\section{References}

Adiger, S.G., Shanthkumar, P.I, Gangashetty and Salimath, P.M. 2011. Association studies in okra (Abelmoschus esculentus (L.) Moench). Electron. J. Pl. Breed. 2(4): 568-573.

Akothar, P.K., De, D.K. and Pal, A. K. 2010. Genetic variability and diversity in okra (Abelmoschus esculentus (L.) Moench). Electron. J. Pl. Breed. 1(4): 393-398. 
Alam, A.K.M.A., and Hossain, M.M. 2006. Variability of different yield contributing parameters and yield of some okra (Abelmoschus esculentus (L.) Moench) accessions. J. Agric. Rural Dev. 4(1\&2): 119127.

Burton, G.W., 1952. Quantitative inheritance in grasses. Proc. $6^{\text {th }}$ Int Grassland Cong. 1: $277-$ 83.

Cochran, W. G., and G. M. Cox. 1957. Experimental Designs. pp. 127-131.

Dhankar, B. S. and Dhankar, S. K. 2002. Genetic variability, correlation and path analysis in okra [Abelmoschus esculentus (L.) Moench]. Veg. Sci. 29(1): 63-68.

Gavade, R.T., and Ghadage, B.A. 2015. Genetic variability, heritability and genetic advance in generation of brinjal (Solanumm elongena L.). Bioinfolet. 12 (1C): 325-328.

Jagan, K., Reddy, K. R, Sujatha, M, Sravanthi, V and Reddy, S. M. 2013. Studies on genetic variability, heritability and genetic advance in okra (Abelmoschus esculentus (L.) Moench). IOSR J. Agric. Vete. Sci. 5(1): 59-61.

Johnson, H. W., Robinson, H. F. and Comstock, R. E. 1955. Estimates of genetic and environmental variability of Soybeans. Agron J. 47: 314-318.

Liang, G.H., and Walter, T.L. 1968. Heritability estimates and gene effects for agronomic trails in grain sorghum. Crop Sci., 8: 77-80.

Lush, J. L., 1940. Inter-size correlation regression of offspring on dairy as a method of estimating heritability of characters. Proc. Amer. Soci.33: 293-301.

Mehta, D. R., Dhaduk, L. K. and Patel, K. D., 2006. Genetic variability, correlation and path analysis studies in okra [Abelmoschus esculentus (L.) Moench]. Agric. Sci. Digest. 26(1): $15-18$.
Mehta, D.R., Dhaduk, L.K. and Patel, K.D. 2006. Genetic variability, correlation and path analysis studies in okra (Abelmoschus esculentus (L.) Moech). Agric. Sci. Digest. 26(1): 15-18.

Oluwa, O.O., and Kehinde, O.B. 2011. Genetic variability studies in West African okra (Abelmoschus caillei). Agric. Biol. J. N. Am. 2(10): 1326-1335.

Panda, P. K., and K. P Singh. 1997. Genetic variability, heritability and genetic advance for pod yield and its contributing traits in okra hybrids. Madras Agric. J., 84: 136-138.

Panse, V.G., 1957. Genetics of quantitative character in relation to plant breeding. Indian J. Genet., 17: 317-28.

Patil, Y.B., Madalageri, B.B., Biradar, B.D. and Hoshmani, R.M. (1996). Variability studies in okra (Abelmoschus esculentus L. Moench.). Karnataka J Agr. Sci 9: 289-293.

Reddy, M.T., Babu, K.H, Ganesh, M, Reddy, K.C, Reddy, B.P. and Narshimulu, G. 2012. Genetic variability analysis for the selection of elite genotypes based on pod yield and quality from the germplasm of okra (Abelmoschus esculentus (L.) Moench). J. Agric. Techol. 8(2): 639-655.

Simon, S.Y., Gashua, I.B and Musa, I. 2013. Genetic variability and trait correlation studies in okra (Abelmoschus esculentus (L.). Moench). Agric. Biol. J. N. Am. 4(5): 532538.

Sivasubramanyam, M.S., and Menon, M. P. 1973. Path analysis of yield components in rice. Madras Agric. Jl. 60(9/12): 1217-1221.

Yonus, M., Garedew, W and Debela, A. 2014. Variability and association of quantitative characters among okra (Abelmoschus esculentus (L.) Moench) collection in south western Ethiopia. J. Biol. Sci. 14(5): 336-342.

\section{How to cite this article:}

Ullangula Sravanthi. 2017. Studies on Variability, Heritability and Genetic Advance in Okra [Abelmoschus esculentus (L.) Moench.]. Int.J.Curr.Microbiol.App.Sci. 6(10): 1834-1838. doi: https://doi.org/10.20546/ijcmas.2017.610.221 